\title{
Regulation of circulating levels of IGF-I in pregnant rats: changes in nitrogen balance correspond with changes in serum IGF-I concentrations
}

\author{
S Nakago, T Funakoshi, Y Ueda and T Maruo \\ Department of Obstetrics and Gynaecology, Kobe University School of Medicine, 7-5-1 Kusunoki-cyo, Chuo-ku, Kobe 650, Japan \\ (Requests for offprints should be addressed to S Nakago)
}

\begin{abstract}
Serum IGF-I concentrations in rats decrease significantly in late pregnancy. To determine if the reduction in serum IGF-I concentrations is attributable to circulating GH or maternal nutritional status, we investigated the effect of treatment with recombinant human GH (rhGH: $100 \mu \mathrm{g} / \mathrm{rat}$ per day) on IGF-I concentrations during late pregnancy, and evaluated the relationship between maternal nitrogen balance and IGF-I concentrations. Serum IGF-I concentrations and maternal nitrogen balance ((nitrogen intake)-(nitrogen content in faeces and urine)-(nitrogen content in fetus and placenta)) were measured by RIA and the Dumas method. In nonpregnant rats treated with rhGH for 3 days, serum IGF-I concentrations $(835 \cdot 4 \pm 59 \cdot 5 \mathrm{ng} / \mathrm{ml} ; \quad P<0 \cdot 01)$ were significantly greater than in those animals treated with saline $(319 \cdot 6 \pm 95 \cdot 6 \mathrm{ng} / \mathrm{ml})$. In the pregnant rats, however, there was no significant difference in serum IGF-I between those treated with $\mathrm{rhGH}(151 \cdot 1 \pm 43 \cdot 0 \mathrm{ng} / \mathrm{ml})$
\end{abstract}

and those treated with saline $(142 \cdot 0 \pm 39 \cdot 9 \mathrm{ng} / \mathrm{ml})$ from day 17 to 19 of pregnancy. Maternal nitrogen balance in the pregnant rats increased significantly from day 4 to day 10 of pregnancy $(169 \cdot 5 \pm 57 \cdot 4$ and $196 \cdot 1 \pm$ $33.4 \mathrm{mg} /$ day, respectively; $P<0 \cdot 05)$ compared with nonpregnant controls $(31.9 \pm 19.9 \mathrm{mg} /$ day $)$ and decreased markedly from day 12 of pregnancy $(79 \cdot 8 \pm 60 \cdot 1 \mathrm{mg} /$ day; $P<0 \cdot 05)$ onwards, to $14 \cdot 9 \pm 47 \cdot 8 \mathrm{mg} /$ day on day 20 of pregnancy $(P<0 \cdot 01)$, significantly different from the value on day 10 of pregnancy. The mean difference in maternal nitrogen balance between pregnant and non-pregnant rats was positively correlated $(r=0 \cdot 87, P<0 \cdot 01)$ with the mean difference in maternal IGF-I concentrations, using linear regression analysis. These results support the conclusion that the circulating concentration of IGF-I in pregnant rats is associated with the change in nitrogen balance, but not with circulating $\mathrm{GH}$.

Journal of Endocrinology (1999) 163, 373-377

\section{Introduction}

Circulating insulin-like growth factor-I (IGF-I) is the major anabolic agent responsible for tissue growth, mediating the effects of growth hormone (GH) (Schoenle et al. 1982). Nutrition, in addition to circulating concentrations of GH (Zapf et al. 1981, Luna et al. 1983), have profound effects upon serum IGF-I concentrations in humans (Clemmons et al. 1981, Merimee et al. 1982, Phillips \& Unterman 1984) and rats (Phillips \& Young 1976). Moreover, serum IGF-I concentrations can be used as a clinical index of nutritional status in nutritionally deprived patients (Clemmons et al. 1985).

Circulating IGF-I concentrations change in pregnancy in a variety of species. Serum IGF-I concentrations in women with an uncomplicated pregnancy are increased in the third trimester and decline rapidly in the early puerperium (Furlanetto et al. 1978, Wilson et al. 1982, Gargosky et al. 1990). These concentrations are regulated by variant $\mathrm{GH}$ secreted by the placenta, but not by the pituitary (Caufriez et al. 1990). In rats, the reduction in serum IGF-I concentrations (Davenport et al. 1990a, Gargosky et al. 1990, Donovan et al. 1991) is observed in late pregnancy, although the circulating concentration of rat GH (rGH) (Terry et al. 1977, Carlsson et al. 1990, Kishi et al. 1991) has an inverse association with serum IGF-I concentrations throughout pregnancy. There are several reports about hormones from the $\mathrm{GH}$-prolactin family in rat placenta (Daughaday et al. 1979, Robertson et al. 1991, Lin et al. 1997), but the effect of these hormones on maternal IGF-I concentrations is unknown at present. Maternal IGF-I concentrations under protein (Pilistine et al. 1984) or food (Monaco \& Donovan 1996) restriction in pregnant rats have also been reported. Nevertheless, the association between the reduction in serum IGF-I concentrations and maternal nutritional status in pregnant rats remains to be elucidated.

In this study, we aimed to determine if the reduction in serum IGF-I concentrations during pregnancy in rats is attributable to circulating $\mathrm{GH}$ or maternal nutritional 
status. The effect of treatment with recombinant human $\mathrm{GH}(\mathrm{rhGH})$ on IGF-I concentrations in pregnant rats was investigated and a possible relationship between the change in nitrogen balance and the reduction in IGF-I concentrations was evaluated.

\section{Materials and Methods}

\section{Animals}

The study procedure was approved by the Committee of Animal Experimentation at Kobe University School of Medicine, and animals were cared for in compliance with the NRC Guide for the Care and Use of Laboratory animals (National Research Council 1985). Rats of the Wistar strain at 8 weeks of age (220-280 g) (Clea Japan, Inc., Osaka, Japan) were bred in a temperature-controlled environment with a 12-h light : 12-h darkness cycle and the day of sperm detection in a vaginal smear was taken as day 1 of pregnancy. Standard food pellets containing $32 \cdot 03 \mathrm{mg} / \mathrm{g}$ nitrogen and water were freely available to all rats. From day 2 to day 20, three to seven rats were decapitated every other day for the collection of samples. Sera were stored at $-20^{\circ} \mathrm{C}$. Any fetuses and placentae were weighed and frozen immediately for storage at $-20{ }^{\circ} \mathrm{C}$. In a metabolic cage, four pregnant rats were housed individually. Body weight, food intake, urine volume and faeces weight were measured daily. Some urine and faeces were stored at $-20{ }^{\circ} \mathrm{C}$. Virgin female rats at 8 weeks of age $(220-280 \mathrm{~g})$ served as non-pregnant controls.

\section{GH treatment in pregnant rats}

Five of the pregnant rats were treated with rhGH $(100 \mu \mathrm{g} / \mathrm{rat}$ per day), provided by Sumitomo Pharmaceuticals (Osaka, Japan), or an equivalent volume of saline, by daily s.c. injections from day 17 to day 19 . On day 20 , the animals were decapitated and sera were collected for subsequent IGF-I measurement. In some experiments, non-pregnant rats were treated with an equivalent volume of rhGH or saline for 3 days.

\section{IGF-I measurement}

Highly purified recombinant IGF-I and polyclonal IGF-I antisera were provided by Fuzisawa Pharmaceutical Co. Ltd (Osaka, Japan). Iodination with [ $\left.{ }^{125} \mathrm{I}\right]$-labelled $\mathrm{Na}$ was performed using the chloramine $\mathrm{T}$ method (Hunter \& Greenwood 1962) to a specific activity of $100-120 \mu \mathrm{Ci} / \mu \mathrm{g} . \quad\left[{ }^{125} \mathrm{I}\right]-$ labelled IGF-I was separated from unincorporated iodine using Sephadex G 25 fine (Pharmacia, Uppsala, Sweden) gel filtration; $60-70 \%$ of the $\left[{ }^{125} \mathrm{I}\right]$-labelled IGF-I was bound at a $1: 10000$ dilution of the antiserum provided. Serum immunoreactive IGF-I

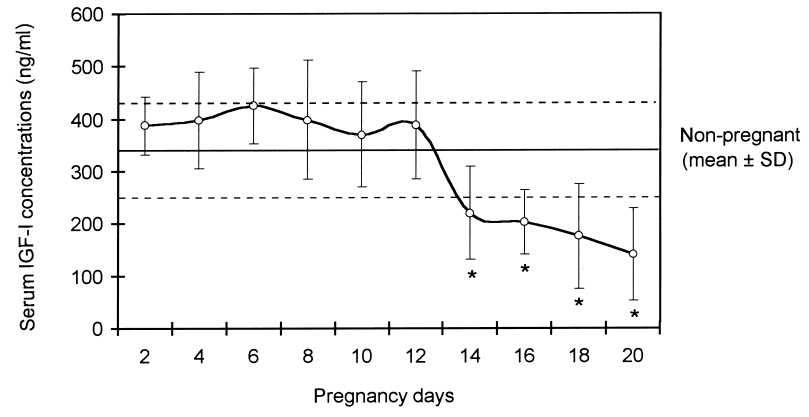

Figure 1 Serum IGF-I concentrations in pregnant rats. Mean values $(\mathrm{ng} / \mathrm{ml})(\bigcirc)$ for four to seven pregnant rats; each bar represents the standard deviation. The mean IGF-I concentration $(-)$ and standard deviations (---) for 10 non-pregnant controls are also shown. ${ }^{*} P<0 \cdot 05$ compared with non-pregnant controls.

was measured by RIA according to the method of Hintz et al. (1982), after removal of IGF binding proteins (IGFBPs) from the samples by Seppak C18 cartridge chromatography (Daughaday et al. 1986).

\section{Nitrogen balance measurement}

Samples of placenta and fetus were homogenised with normal saline. Nitrogen content was measured in these homogenised samples, in addition to faeces and urine, using the Dumas method (Bellomonte et al. 1987). Maternal nitrogen balance was defined as follows: (maternal nitrogen balance $)=($ nitrogen intake $)-($ nitrogen content in the faeces and urine)-(nitrogen content in fetuses and placentae).

\section{Statistical analysis}

Statistical analysis was performed using the unpaired Student's $t$-test or regression analysis as appropriate. Statistical significance was accepted at the $<0.05$ level.

\section{Results}

\section{Serum IGF-I concentrations in pregnant rats}

Serum IGF-I concentrations until day 12 (388.2 \pm $102.7 \mathrm{ng} / \mathrm{ml}$, means \pm s.D.) were unchanged compared with those in non-pregnant controls $(327 \cdot 6 \pm 92 \cdot 8 \mathrm{ng} / \mathrm{ml})$. The concentrations on day $14(220 \cdot 3 \pm 88 \cdot 8 \mathrm{ng} / \mathrm{ml})$ decreased significantly compared with those in nonpregnant controls $(P<0 \cdot 05)$. This decrease was observed until pregnancy was terminated (Fig. 1).

\section{Serum IGF-I concentrations in pregnant and non-pregnant rats treated with rhGH}

Serum IGF-I concentrations $(835 \cdot 4 \pm 59 \cdot 5 \mathrm{ng} / \mathrm{ml} ; \quad P<$ $0 \cdot 01)$ were significantly greater in non-pregnant rats 
Table 1 Effects of hGH treatment on serum IGF-I concentrations in pregnant rats. Values are means \pm S.D.

\begin{tabular}{llll} 
& \multicolumn{2}{l}{ Serum IGF-I conc. $(\mathrm{ng} / \mathrm{ml})$} & \\
\cline { 2 - 2 } $\begin{array}{c}\text { Treatment } \\
\text { Saline }\end{array}$ & $319 \cdot 6 \pm 95 \cdot 6$ & & Pregnant rats \\
\cline { 2 - 3 } & GH & $835 \cdot 4 \pm 59 \cdot 5^{*}$ & $142 \cdot 0 \pm 39 \cdot 9$ \\
& & $151 \cdot 1 \pm 43 \cdot 0$ \\
\hline
\end{tabular}

${ }^{*} P<0.001$ compared with non-pregnant controls treated with saline by unpaired Student's $t$-test.

treated with rhGH than in those treated with saline $(319.6 \pm 95.6 \mathrm{ng} / \mathrm{ml})$. In the pregnant rats, however, serum IGF-I concentrations after treatment with rhGH $(151 \cdot 1 \pm 43 \cdot 0 \mathrm{ng} / \mathrm{ml})$ showed no significant difference from those after treatment with saline $(142 \cdot 0 \pm 39 \cdot 9$ $\mathrm{ng} / \mathrm{ml})$ (Table 1).

\section{Maternal nitrogen balance in pregnant rats}

Maternal nitrogen balance in the pregnant rats significantly increased from day $4(169 \cdot 5 \pm 57 \cdot 4 \mathrm{mg} /$ day; $P<0 \cdot 05)$ to day $10(196.1 \pm 33.4 \mathrm{mg} /$ day; $P<0 \cdot 05)$ compared with that in the non-pregnant controls $(31.9 \pm$ $19.9 \mathrm{mg} /$ day). The balance decreased markedly from day $12(79 \cdot 8 \pm 60 \cdot 1 \mathrm{mg} /$ day; $P<0 \cdot 05)$ onwards, to a value of $14.9 \pm 47 \cdot 8 \mathrm{mg} /$ day on day $20(P<0.01$ compared with that on day 10) (Fig. 2). The association between maternal IGF-I concentrations and nitrogen balance was examined using linear regression analysis. The mean difference in maternal nitrogen balance between pregnant rats and

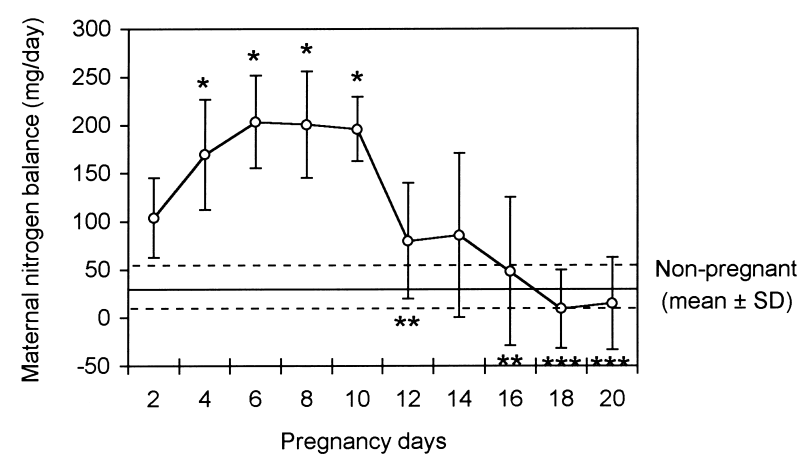

Figure 2 Maternal nitrogen balance (calculated as (maternal nitrogen balance $)=($ total nitrogen intake $)-($ nitrogen content in faeces and urine)-(nitrogen content in fetus and placenta)) in pregnant rats. Mean values $(\mathrm{mg} /$ day) $(\bigcirc)$ for four pregnant rats; each bar represents the standard deviation. The mean nitrogen balance $(-)$ with standard deviations (---) for four non-pregnant controls are also shown. ${ }^{*} P<0.05$ compared with non-pregnant controls; ${ }^{* *} P<0 \cdot 05,{ }^{* *} P<0 \cdot 01$ compared with day 10 .

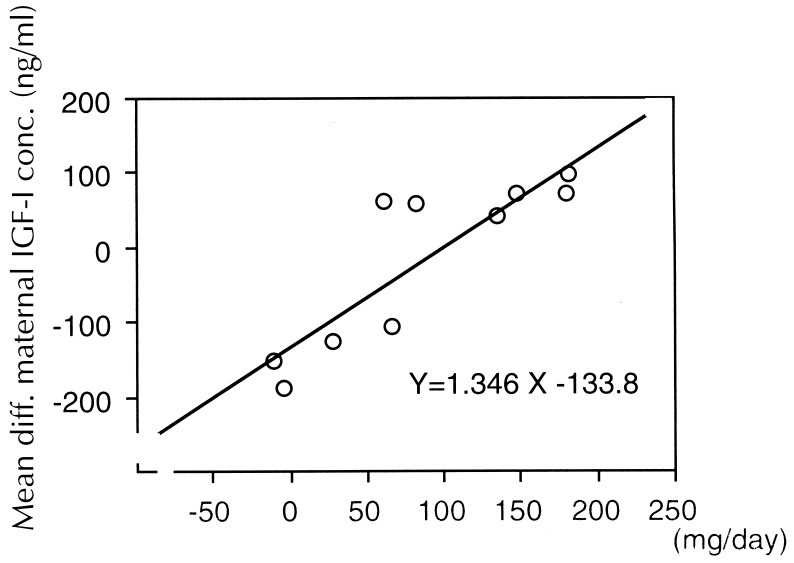

Mean diff. maternal nitrogen balance

Figure 3 Mean difference (diff.) in maternal nitrogen balance in relation to the mean difference (diff.) in serum IGF-I concentrations during pregnancy in rats. Differences are expressed as those between pregnant rats and non-pregnant controls. There is a significant correlation between these two variables: $r=0 \cdot 87$, $P<0.01$; linear regression analysis.

non-pregnant controls was positively correlated $(r=0 \cdot 87$, $P<0 \cdot 01)$ with the mean difference in maternal IGF-I concentrations (Fig. 3).

\section{Discussion}

No increment in serum IGF-I concentrations after treatment with rhGH was observed in our study, which strongly suggests that serum circulating GH does not have an important role in the regulation of maternal IGF-I during pregnancy in rats. This finding demonstrates that an apparent GH resistance occurs in late pregnancy in rats, as indicated in previous reports (Gargosky et al. 1991, Travers et al. 1993, Spence et al. 1995). In contrast with our results, Chiang \& Nicoll (1991) reported that GH treatment retained the ability to increase IGF-I in rat pregnancy. The reason for this discrepancy may be that different concentrations of $\mathrm{GH}$ were used in the experiments: the pregnant rats in our study were administered $100 \mu \mathrm{g} /$ day human $\mathrm{GH}$ for 3 days, whereas Chiang \& Nicoll administered $1 \mathrm{mg} /$ day bovine $\mathrm{GH}$ or $5 \mathrm{mg}$ /day ovine GH for 9 days. This hypothesis is supported by a report (Spence et al. 1995) that showed that circulating IGF-I concentrations in pregnant rats are significantly increased on day 21 after treatment with $5 \mathrm{IU} / \mathrm{kg}$ per day porcine GH from day 6 to day 21, but not after treatment with $1 \mathrm{IU} / \mathrm{kg}$ per day.

Nutritional influences are likely to have a major effect on circulating IGF-I concentrations under acquired GH resistance, because GH resistance is a commonly recognised feature of protein catabolic status (Donaghy \& Baxter 
1996). Indeed, the association of circulating IGF-I with nitrogen balance is observed in fasted volunteers (Clemmons et al. 1981) and malnourished patients (Clemmons et al. 1985). In our study, we have demonstrated, for the first time, a close relation between maternal IGF-I concentration and nitrogen balance during pregnancy in rats.

The mechanism of $\mathrm{GH}$ resistance during rat pregnancy remains unclear. Hepatic GH binding activity does not vary during pregnancy (Travers et al. 1993). Furthermore, a recent study has shown that hepatic GH receptor and $\mathrm{GH}$ binding protein gene expression are not suppressed by maternal malnutrition during rat pregnancy (Woodall et al. 1998). These reports suggest that a possible postreceptor defect in $\mathrm{GH}$ action may contribute to $\mathrm{GH}$ resistance observed in pregnant rats.

The reduction in circulating IGF-I in pregnant rats may also be associated with the effect of IGFBP, presumed to have an important role in determining the biological actions of IGF-I in various tissues (Jones \& Clemmons 1995). The predominant IGFBP in blood is IGFBP-3, part of a ternary complex with IGF-I peptide and an acid labile subunit (Furlanetto 1980, Baxter 1988). This complex serves as the endocrine storage depot for IGF-I, which extends the half-lives of IGF-I peptides in the circulation (Zapf et al. 1986, Cascieri et al. 1988, Francis et al. 1988). In rats, IGFBP-3 concentrations are decreased in late pregnancy (Davenport et al. 1990a, Gargosky et al. 1990), in spite of unchanged hepatic expression of IGFBP-3 mRNA (Donovan et al. 1991). The reduction in IGFBP-3 concentrations is regulated by intrinsic proteases, such as serine proteases and matrix metalloproteinases (Davenport et al. 1992, Fowlkes et al. 1994). Although lower hepatic concentrations of IGF-I are observed in late pregnant rats than in non-pregnant rats (Davenport et al. 1990a), maternal IGF-I concentrations are likely to be reduced because of proteolysis of circulating IGFBP-3 (Davenport et al. 1992). According to Davies et al. (1991), malnutrition during severe illness in humans induces the activity of serum proteases specific for IGFBP-3. From these investigations, the reduction in circulating IGF-I in pregnant rats might be attributable to the proteolysis of IGFBP-3 in maternal serum under maternal malnutrition. Whether the reduction in circulating concentrations of IGF-I results from the suppression of IGF-I hepatic production or from the proteolysis of IGFBP-3 remains to be investigated.

IGF-I peptide acts by stimulating anabolic metabolism in tissues, as shown by the increase in nitrogen balance induced by IGF-I treatment in humans (Tomas et al. 1991). Restricting maternal protein intake reduces fetal growth retardation and maternal IGF-I concentrations (Davenport et al. 1990b; Muaku et al. 1995). In undernourished pregnant rats, increases in maternal IGF-I concentrations induced by treatment with high doses of ovine or bovine GH led to reductions in fetal growth, whereas maternal body weight increases (Chiang \& Nicoll
1991). From these results and our own, we assume that the reduction in circulating IGF-I concentrations during late pregnancy in rats may be necessary for the inhibition of maternal anabolic metabolism and redistribution of maternal nutrients to support fetal growth.

In summary, we have provided evidence suggesting that there is an association between maternal nitrogen balance and serum IGF-I concentrations in pregnant rats. We are not aware of any study in pregnant women assessing the relationship between maternal nutritional status and serum IGF-I concentration. Further studies will be necessary to understand better how IGF-1 is regulated in pregnant women with nutritional and metabolic disorders.

\section{Acknowledgements}

The authors wish to thank Dr Stephen Kennedy, Oxford, UK, for his critical review of this manuscript.

\section{References}

Baxter RC 1988 Characterization of acid-labile subunit of growth hormone-dependent insulin-like growth factor binding protein complex. Journal of Clinical Endocrinology and Metabolism 67 265-272.

Bellomonte G, Costantini A \& Giammarioli S 1987 Comparison of modified automatic Dumas method and the traditional Kjeldahl method for nitrogen determination in infant food. Journal of the Association of Official Analytical Chemists 70 227-229.

Carlsson L, Eden S \& Jansson J-O 1990 The plasma pattern of growth hormone in conscious rats during late pregnancy. Journal of Endocrinology 124 191-198.

Cascieri MA, Saperstein R, Hayes NS, Green BG, Chicchi GG, Applebaum J \& Bayne ML 1988 Serum half-life and biological activity of mutants of human insulin-like growth factor I which do not bind to serum binding proteins. Endocrinology 123 373-381.

Caufriez A, Frankenee F, Englert Y, Golstein J, Cantraine F, Hennen G \& Copinschi G 1990 Placental growth hormone as a potential regulator of maternal IGF-I during human pregnancy. American Journal of Physiology 258 E1014-1019.

Chiang MH \& Nicoll CS 1991 Administration of growth hormone to pregnant rats on a reduced diet inhibits growth of their fetuses. Endocrinology 129 2491-2495.

Clemmons DR, Klibanski A \& Underwood LE 1981 Reduction of plasma immunoreactive somatomedin $\mathrm{C}$ during fasting in humans. Journal of Clinical Endocrinology and Metabolism 53 1247-1250.

Clemmons DR, Underwood LE, Dickerson ND, Brown RO, Hak LJ, MacPhee RD \& Heizer WD 1985 Use of plasma somatomedin $\mathrm{C} /$ insulin-like growth factor I measurements to monitor the response to nutritional repletion in malnourished patients. American Journal of Clinical Nutrition 41 191-198.

Daughaday WH, Trivedi B \& Kapadia M 1979 The effect of hypophysectomy on rat chorionic somatomammotropin as measured by prolactin and growth hormone radioreceptor assays: possible significance in maintenance of somatomedin generation. Endocrinology 105 210-214.

Daughaday WH, Canou CE \& Kapadia M 1986 Insulin-like growth factor I and II in maternal and fetal guinea pig serum. Endocrinology 119 490-494.

Davenport ML, Clemmons DR, Miles MV, Camacho-Humber C, D'Ercole AJ \& Underwood LE 1990a Regulation of serum insulinlike growth factor I (IGF-I) and IGF binding proteins during rat pregnancy. Endocrinology 127 1278-1286. 
Davenport ML, D'Ercole AJ \& Underwood LE 1990b Effect of maternal fasting on fetal growth, serum insulin-like growth factors (IGFs), and tissue IGF messenger ribonucleic acids. Endocrinology $1262062-2067$.

Davenport ML, Pucilowska J, Clemmons DR, Lundblad R, Spencer JA \& Underwood LE 1992 Tissue specific expression of insulin-like growth factor binding protein-3 protease activity during rat pregnancy. Endocrinology 130 2505-2512.

Davies SC, Wass JAH \& Ross RJM 1991 The induction of a specific protease for insulin-like growth factor binding protein-3 in the circulation during severe illness. Journal of Endocrinology 130 496-473.

Donaghy AJ \& Baxter RC 1996 Insulin-like growth factor bioactivity and its modification in growth hormone resistant states. Baillière's Clinical Endocrinology and Metabolism 10 421-446.

Donovan SM, Giudice LC, Murphy LJ, Hintz RL \& Rosenfeld RG 1991 Maternal insulin-like growth factor-binding protein messenger ribonucleic acid during rat pregnancy. Endocrinology 129 3359-3365.

Fowlkes JL, Suzuki K, Nagase H \& Thraikill KM 1994 Proteolysis of insulin-like growth factor binding protein-3 during rat pregnancy: a role for matrix metalloproteinases. Endocrinology 135 2810-2813.

Francis GL, McNamara PJ, Filsell OH \& Ballard FJ 1988 Plasma half-lives of native and modified insulin-like growth factor-I in lambs. Journal of Endocrinology 117 183-189.

Furlanetto RW 1980 Somatomedin C binding protein. Evidence for a heterologous subunit structure. Journal of Clinical Endocrinology and Metabolism 51 12-19.

Furlanetto RW, Underwood LE, Van Whk JJ \& Handwerger S 1978 Serum immunoreactive somatomedin-C is elevated late in pregnancy. Journal of Clinical Endocrinology and Metabolism 47 695-698.

Gargosky SE, Walton PE, Owens JA, Wallace JC \& Owens PC 1990 Circulating levels of insulin-like growth factors increase and molecular forms of their serum binding proteins change with human pregnancy. Biochemical and Biophysical Research Communication 170 1157-1163.

Gargosky SE, Owens JA, Walton PE, Owens PC, Wallace JC \& Ballard FJ 1991 Administration of insulin-like growth factor-I, but not growth hormone, increases maternal weight gain in late pregnancy without affecting fetal or placental growth. Journal of Endocrinology 130 395-400.

Hintz RL, Liu F \& Seegan G 1982 Characterization of an insulin-like growth factor-I/somatomedin-C radioimmunoassay specific for the C-peptide region. Journal of Clinical Endocrinology and Metabolism $\mathbf{5 5}$ 927-930.

Hunter WH \& Greenwood FC 1962 Preparation of iodine-131 labelled human growth hormone of high specific activity. Nature 194 495-496.

Jones J \& Clemmons DR 1995 Insulin-like growth factors and their binding proteins: biological actions. Endocrine Reviews 16 3-34.

Kishi K, Hirahashi M \& Hasegawa Y 1991 Gestational profiles of rat placental lactogen-II (rPL-II) and growth hormone $(\mathrm{GH})$ in maternal and fetal serum, amniotic fluid and placental tissue. Endocrinologia Japonica 38 589-595.

Lin J, Poole J \& Linzer DIH 1997 Three new members of the mouse prolactin/growth hormone family are homologous to proteins expressed in the rat. Endocrinology 138 5541-5549.

Luna AM, Wilson DM, Wibbelsman CJ, Brown RC Nagashima RJ, Hintz RL \& Rosenfeld RG 1983 Somatomedins in adolescence: a cross-sectional study of puberty in plasma insulin-like growth factor I and II levels. Journal of Clinical Endocrinology and Metabolism 57 268-271.

Merimee TJ, Zapf J \& Froesch ER 1982 Insulin-like growth factors in the fed and fasted states. Journal of Clinical Endocrinology and Metabolism 55 999-1002.
Monaco MH \& Donovan 1996 Moderate food restriction abolishes the pregnancy-associated rise in serum growth hormone and decreases serum insulin-like growth factor-I (IGF-I) concentrations without altering IGF-I mRNA expression in rats. Journal of Nutrition 126 $544-553$

Muaku SM, Beauloye V, Thissen JP, Underwood LE, Ketelslegers JM \& Maiter D 1995 Effects of maternal protein malnutrition on fetal growth, plasma insulin-like growth factor binding proteins, and liver insulin-like growth factor expression in the rat. Pediatric Research 37 334-342.

National Research Council 1985 Guide for the Care and Use of Laboratory Animals. Publication No. 85-23(rev). Bethesda: NIH.

Phillips LS \& Young HS 1976 Nutrition and somatomedin I. Effect of fasting on serum somatomedin activity and cartilage growth activity in rats. Endocrinology 99 304-314.

Phillips LS \& Unterman TG 1984 Somatomedin activity in disorders of nutrition and metabolism. Clinics in Endocrinology and Metabolism 13 145-189.

Pilistine SJ, Moses AC \& Munro HN 1984 Placental lactogen administration reverses the effect of low-protein diet on maternal and fetal serum somatomedin levels in the pregnant rat. Proceedings of the National Academy of Sciences of the USA 81 5853-5857.

Robertson MC, Schroedter LC \& Friesen HG 1991 Molecular cloning and expression of rat placental lactogen-Iv, a variant of rPL-I present in late pregnant rat placenta. Endocrinology 129 2746-2756.

Schoenle E, Zapf J \& Humberl ER 1982 Insulin-like growth factor I stimulates growth in hypophysectomized rats. Nature 296 252-253.

Spence S, Mattson B, Vetter C, Cukierski M \& Prahalada S 1995 Effects of porcine growth hormone on pregnancy and fetal/neonatal development in the rat. Biology of the Neonate 68 62-74.

Terry LC, Saunders A, Audet J, Willoughby JO, Brazemau P \& Martin JB 1977 Physiologic secretion of growth hormone and prolactin in male and female rats. Clinical Endocrinology 6 (suppl) $19-28$.

Tomas FM, Knowles SE, Owens PC, Read LC, Chandler CS, Gargosky SE \& Ballard FJ 1991 Effects of full-length and truncated insulin-like growth factor-I on nitrogen balance and muscle protein metabolism in nitrogen-restricted rats. Journal of Endocrinology 128 97-105.

Travers MT, Madon RJ \& Flint DJ 1993 Regulation of serum insulin-like growth factor-I (IGF-I), hepatic growth hormone binding and IGF-I gene expression in the rat during pregnancy and lactation. Journal of Endocrinology 139 89-95.

Wilson DM, Benett A, Adamson GD, Nagashima RJ, Liu F, DeNatale ML, Hinz RL \& Rosenfeld RG 1982 Somatomedins in pregnancy: a cross-sectional study of insulin-like growth factors I and II and somatomedin peptide content in normal human pregnancies. Journal of Clinical Endocrinology and Metabolism $\mathbf{5 5}$ 858-861.

Woodall SM, Bassett NS, Gluckman PD \& Breier BH 1998 Consequences of maternal undernutrition for fetal and postnatal hepatic insulin-like growth factor-I, growth hormone receptor and growth hormone binding protein gene regulation in the rat. Journal of Molecular Endocrinology 20 313-326.

Zapf J, Walter H \& Froesch ER 1981 Radioimmunological determination of insulin-like growth factors I and II in normal subjects and in patients with growth hormone disorders and extrapancreatic tumor hypoglycemia. Journal of Clinical Investigation 68 1321-1332.

Zapf J, Hauri C, Waldvogel M \& Froesch ER 1986 Acute metabolic effects and half-lives of intravenously administered insulin-like growth factors I and II in normal and hypophysectomized rats. Journal of Clinical Investigation 77 1768-1775.

Received 26 March 1999

Accepted 6 July 1999 